\title{
Neke smjernice za pastoral braka i obitelji prema aspostolskoj pobudnici Amoris Laetitia (I.)
}

\author{
IVAN ŠARČEVIĆ* \\ • https://doi.org/10.31823/d.29.1.3 • \\ UDK: 27-45-555 - Izvorni znanstveni rad \\ Primljeno: 8. travnja 2020. P Prihvaćeno: 12. veljače 2021.
}

Sažetak: Prvi dio članka »Neke smjernice za pastoral braka $i$ obitelji prema apostolskoj pobudnici Amoris laetitia «želi istaknuti kako je posinodalna pobudnica o ljubavi u obitelji Amoris laetitia (2016.) opečaćena pastoralnom teologijom pape Franje koju nastavlja na svoju programsku pobudnicu Evangelii gaudium (2013.). Oznake te teologije jesu svetopisamsko utemeljenje i jezična aktualizacija, argentinska teologija naroda, isusovačka duhovnost s naglaskom na samoodgoj kroz oblikovanje savjesti i razlučivanje duhova; ekleziologija Drugoga vatikanskoga koncila s naglaskom na Crkvu otvorenih vrata i izlaska na periferije. Riječ je o pastoralno orijentiranom govoru o Bogu postupnoga odgoja i bezuvjetnoga milosrđa. Riječ je o čovjeku, ljubljenom Božjem stvorenju koje nije savršeno, ali je pozvano da se odgaja, da ljubi i tako se postu-

* Prof. dr. sc. Ivan Šarčević, Franjevačka teologija Sarajevo, Aleja Bosne Srebrene 111,71000 Sarajevo, Bosna i Hercegovina, ivansarst@gmail.com pno, malim koracima, u braku i obitelji, u kršćanskoj zajednici i svijetu suobličuje Isusu Kristu. U ovome se dijelu članka progovara o posebnim pastoralnim smjernicama koje proizlaze iz pobudnice Amoris laetitia, a koje se odnose na pripremu za brak i na pastoralno praćenje bračnih drugova i obitelji.

Ključne riječi: obitelj, ljubav, Bog milosrda, Crkva izlaska, savjest, pastoral praćenja i razlučivanja.

\section{Uvod}

Da bismo bolje razumjeli posinodalnu pobudnicu Amoris laetitia, nužno je barem ukratko osvrnuti se na percepciju pape Franje, glavnoga protagonista dviju biskupskih sinoda (izvanredne 2014. i redovne 2015. godine) te autora i 
potpisnika te pobudnice o ljubavi u obitelji. Smatramo također korisnim reći nekoliko riječi i o njegovoj teologiji. Naime nakon Benedikta XVI., pape teologa, koji se čak sučeljavao s nekim teolozima do njihove suspenzije, pogotovo dok je bio prefekt Kongregacije za nauk vjere, a omiljena antiteološki raspoloženim biskupima, svećenicima i duhovnicima, njegova nasljednika papu Franju bije glas da uopće nije teolog. Podržavaju ga međutim mnogi intelektualci svijeta koji nisu ni teolozi, ni katolici, ni kršćani, a osporavaju ga protivnici knjige i studija teologije, kao i oni koji nostalgično prizivaju prethodni pontifikat pape teologa.

Od kada je izabran za papu, papa Franjo ne prestaje izazivati pozornost, pa i sporenja. U cjelini gledano, poslije pape Ratzingera papa Bergoglio za neke - ponajprije u Katoličkoj Crkvi i to prije svega u njezinu hijerarhijskom dijelu - djeluje ne samo različit od prethodnoga Pape nego i kao neugodan remetilački čimbenik. Neki čak idu dotle da smatraju da Bergoglio nije izabran za papu niti vodi Crkvu po Duhu Božjem, nego da su ga urotnički postavili neprijatelji. I u našoj krajevnoj Crkvi, i u Hrvatskoj i u Bosni i Hercegovini, papu Franju prihvaća se većinom kao nužnost, s prešutnim protivljenjem. Dijelom je to iz općih razloga njegove drugosti, dijelom iz njegovih riječi i gesta u koje spadaju primjerice razumijevanje Crkve siromašnih, poimanje i prihvat migranata i s njima povezani problem islama i međureligijskoga dijaloga, zatim shvaćanje ekumenizma. Dobrim dijelom odbijanje sadašnjega Pape u našoj Crkvi dolazi i iz religiozno-političkih razloga, iz opterećene prošlosti i nepročišćene memorije, konkretno, iz povijesno opterećenoga i spoticajnoga odnosa sa Srpskom pravoslavnom Crkvom, zbog Papina otezanja da proglasi A. Stepinca svetim.

U odnosu na prijašnje pape, u nas je papa Franjo prilično malo citiran u biskupskim poslanicama, svećeničkim propovijedima, teološkim radovima i katehetskim poukama. Dijelom je to i stoga što njegovi spisi i govori nisu pravno usustavljeni, apodiktički, nego su prepuni metafora. Nijedna se od naših biskupskih konferencija nije pozabavila njegovim važnim dokumentima, nastupnom i programskom enciklikom Evangelii gaudium (2013.), a ni posinodalnom pobudnicom o ljubavi u obitelji Amoris laetitia (2016.), o kojoj je raspravljala i svoje dokumente donijela većina biskupskih konferencija svijeta i koja je u javnosti izazivala prijepore i raspre. ${ }^{1}$

\footnotetext{
${ }^{1}$ Prema našem uvidu, vjerojatno najcjelovitije djelo o nastanku, stilu, novinama, o kontinuitetu s učiteljstvom, zatim o dvjema sinodama, percepciji, prihvatu i osporavanju pobudnice pape Franje Amoris laetitia (AL), posebno s aspekta razvedenih koji žive u novoj vezi jest pozamašni i literaturom vrlo potkrijepljeni doktorski rad: M. OMETTO, Divorziati che vivono una nuova unione nella Chiesa cattolica. Da Familaris consortio ad Amoris laetitia, Canterano (RM), 2018. Vrijedna analiza pobudnice $s$ raznih aspekata koju je načinilo 30-ak njemačkih teologa nalazi se u pozamašnom zborniku članaka: G. AUGUSTIN, I. PROFT (ur.), Zum Gelingen von Ehe und Familie. Ermutigung aus Amoris laetitia (Für Walter Kardinal Kasper), Freiburg-Basel-Wien, 2018.
} 
Nisu to ozbiljnije učinila ni katolička teološka učilišta, ni pojedine crkvene institucije, ni pastoralna vijeća (za brak i obitelj) pri biskupijama, a ni katolički mediji, osim objavljivanja osnovnih vijesti. Tek se nešto malo više javno govorilo i raspravljalo o Papinoj ekološkoj pobudnici Laudato si' (2015.), i to redovito na inicijativu vjernika laika, znanstvenika neteologa ili ljudi zagovornika očuvanja prirode.

\section{Ekleziologija i teologija pape Franje}

Više nego što je Slaven, Poljak Wojtyla svojim izborom za papu uznemirio onodobne duhove i ustaljene sheme, pogotovo u vatikanskoj aparaturi, učinio je to $\mathrm{Ar}$ gentinac Bergoglio. Papa Franjo ostat će čitava svoga pontifikata za neke, i to neke važne ljude u Crkvi, osobom koja se našla, ako ne na pogrješnom, ali zacijelo na neprikladnom mjestu. Zapravo, to ima veze $s$ crkvenim podrijetlom i poimanjem Crkve, ekleziologijom.

Papa Bergoglio dolazi s periferije, nije europski papa, pa i Crkvu razumijeva kao Crkvu periferije. To je za neke, ponajprije crkvene centraliste, nedostatak, a za druge prednost jer smatraju da i Gospodin Isus dolazi s periferije, iz Nazareta; iz omražene i poganske Galileje krenuo je njegov pokret bratske zajednice, poruka Božjega kraljevstva i stvaranje Crkve. Uostalom, mnoge važne promjene u povijesti Crkve dogodile su se iz manjih i perifernih mjesta, poput pustinje, osama, samostana. $\mathrm{Pa}$ i hodočasnička i proštenička mjesta, i stara i suvremena, uvijek su neka vrsta periferije i, vjerničko-teološki gledano, nerijetko su ih snažno osporavala hijerarhijska središta, ali i akademski crkveni krugovi.

Sinodalnost i policentrično razumijevanje Crkve, na što današnji papa stalno upozorava, ističe važnost pojedinih kultura i malih lokalnih Crkava. ${ }^{2}$ Točno je da papa Franjo naglašava da je »vrijeme iznad prostora «, da određena vrsta idealizma ili utopije treba pokretati kršćane svijeta da izgrađuju čitav svijet, da se slijepo ne drže svoga lokalizma, da posvuda budu gostoljubivi za obespravljene, prognane i izbjegle. No on pritom nikada ne niječe, nego upravo naglašava neporecivu važnost svake pojedine Crkve i naroda. Inkarnacijski karakter kršćanstva potvrda je temeljne istine vjere o Božjem dolasku na zemlju i uzimanje kao svoga svega onoga što je konkretno ljudsko i zemaljsko (osim grješnosti). To onda znači poštovanje jezičnih, kulturnih, običajnih posebnosti pojedinih mjesnih Crkava i crkvenih zajednica.

${ }^{2}$ Prema J. F. Keenanu vjerojatno najvažniji pastoralni nauk o Crkvi na II. vatikanskom koncilu jest priznanje lokalnih Crkava. To čini i papa Franjo (usp. J. F. KEENAN, Amoris laetitia: Trasformazione della teologia pastorale e trasformazione della Chiesa, u: A. AUTIERO (ur.), Per una nuova cultura pastorale. Il contributo di Amoris laetitia, Cinisello Balsamo [Milano], 2019., 46.). 
Današnjega Papu stoga valja promatrati kao vjernika, svećenika, biskupa, Latinoamerikanca, Argentinca, sa svim vlastitostima, osobnim, ali i kolektivnim oznakama geografskoga, povijesno-društvenoga i crkveno-redovničkoga konteksta. Bergoglio je zaigrani južnjak, s mediteransko-talijanskim nasljeđem, komunikativan i familijaran, čovjek iz naroda, formiran na pučkoj, obiteljskoj i župnoj pobožnosti, odgajan i školovan u ignacijanskoj duhovnosti i španjolskoj mistici križa i patnje, slikovito-poetičnoga jezika ${ }^{3}$, ali i strogoće latinoameričkih vođa.

Čini se presudnim da Bergoglio osobnu prirodu i svoju ambijentalnu uvjetovanost najvećim dijelom odgaja i korigira Svetim pismom, odnosno evanđeljem milosrđa ${ }^{4}$, kao i franjevačkom spontanošću, bolje kazano, neposrednošću i nježnošću Franje Asiškoga kojom su ozračeni romanski narodi te ništa manjim dijelom i ignacijanskim načelom razlučivanja duhova, vojničkim samoodgojem savjesti, kao i služiteljsko-predanim stavom prema Crkvi, a sve na veću proslavu Boga.

Neki će naslov teologija pape Franje označiti preuzetnim. Smatramo međutim da on može stajati. Bergoglio, doduše, nije ni blizu tipu teologa kakav je njegov prethodnik Benedikt XVI., pa ni poput Ivana Pavla II. koji je imao svojih filozofskoteoloških spisa s naglaskom na antropologiju ${ }^{5}$, pa ni poput Pavla VI., pape II. vatikanskoga koncila, koji je, kao aristokrat duha, jezičnom suptilnošću raspravljao i pisao o evangelizaciji i teškom pitanju suvremene Crkve - odnosu vjere i kulture. Papa Franjo, imajući u vidu kontekst njegova podrijetla, sličan je papi Ivanu XXIII.,

\footnotetext{
${ }^{3}$ Prema nekim autorima papa Franjo obnavlja crkveni jezik. Riječ je o novom lingvističkom događaju u Crkvi. Govori se o familijarnom jeziku pobudnice Amoris laetitia (AL). Fares donosi izvadak iz Papina govora na kraju sinode (2015.) u kojem Papa uočava »zamke « jezika: zamka preuzetnosti da se našlo konačno rješenje za sve slučajeve; zamka neslušanja i nerazgovaranja; zamka »anesteziranih savjesti «; zamka tvrdoga srca i korištenje doktrinarnim normama kao kamenjem protiv slabih; zamka zahrđalosti staroga jezika koji nije razumljiv; zamka da se brani slovo, a ne duh, ideje, a ne čovjeka, formule, a ne besplatnost Božje ljubavi i njegova praštanja; zamka da se distribuiraju anateme i osude umjesto da se navijesti milosrđe i poziv na obraćenje (usp. D. FARES, Amoris laetitia e il rinnovamento del linguaggio ecclesiale, u: FRANCESCO, Amoris laetitia. Esortazione apostolica postsinodale sull'amore nella famiglia, Milano, 2016., 230.). Teolog Bruno FORTE, u uvodu za knjigu: A. AUTIERO (ur.), Per una nuova cultura pastorale (bilj. 2), smatra da je riječ o konkretnom i kolokvijalnom jeziku koji time ništa manje nije evokativan i poetičan (str. 10.).

${ }^{4}$ Evo kako izričito spaja evanđelje i jezik naviještanja koji ne smije biti osuda ni indoktrinacija, ako Crkva ne bude majka koja razumije, tješi i prihvaća, nego ona koja baca kamenje osude na svoju slabu djecu: »Na taj način, umjesto da ponude ljekovitu moć milosti i svjetla evanđelja, neki žele 'indoktrinirati' poruku evanđelja, pretvarajući ga u 'kamenje koje se baca na druge' (AL 49).«

${ }^{5}$ Vrlo vrijedna knjiga u kojoj autor uspoređuje nauk Ivana Pavla II. i nauk pape Franje u kontinuitetu personalističkoga razumijevanja čovjeka pojedinca, kao osobe, kao i razlikovanje objektivnoga i subjektivnoga te da je konkretni čovjek, nesvediv na narav, polazište i srž pobudnice AL, kao i o tome da papa Franjo stoji između kazuistike i situacijske etike: H. VARGIĆ, Amoris laetitia: vjernost ili lom. Od Wojtyle do pape Franje, Zagreb, 2019., ovdje 194.
} 
koji se nazivao »župnikom svijeta «, jer u sličnom duhu pastira želi susretati svijet i voditi Crkvu. Oba se vode gotovo istim načelom: umjesto anateme i manihejskoga pogleda na čovjeka i svijet, crkveni pastiri trebaju navješćivati i darivati Božje, Isusovo milosrđe; umjesto bijega, obrane i zatvaranja od svijeta, Crkva i svećenici trebaju ići među ljude, do nekatolika i nekršćana, sve do periferija svijeta.

Bergogliova teologija jest biblijski prožeta; suvremeni život prosuđuje u svjetlu Božje riječi. ${ }^{6}$ Papa neumorno propovijeda i katehizira na osnovi svetopisamskih čitanja. Njegovu biblijsku teologiju ili, ako je to preuzetno reći, njegov pristup u razumijevanju i tumačenju Svetoga pisma određen je redukcijom na temeljnu poruku, na kerygmu, o čemu govori i piše. Kerygma je životna, spasenjska poruka koja pojedinca i narod poziva na obraćenje. Kerygma je sažeta egzistencijalna, iskustvena istina da me je Bog dotaknuo i da je odnos s njime moj temeljni odnos koji me se bezuvjetno tiče i na kojem gradim svoju osobnost. Ta se kerygma najprije svjedoči i prenosi u obitelji , bližnjima, a onda se širi dalje.

Kerygma je na najmanju jezičnu mjeru, na kratku formulu sveden proces evangelizacije. Imajući to u vidu, može nam biti jasno zašto u Papinu govoru elipsâ i metaforâ ima jezične nedorađenosti, semantičke zbrke, pa i pretjerivanja, tako da njegova poruka izgleda nekada kao da je na rubu populizma. Velimo na rubu jer smatramo da je Papa više orijentiran da istina vjere, poruka evanđelja stigne ljudima nego da istakne svoje iskustvo i svoju umnost. Možemo kazati da je Papin govor i pisanje više kerigmatska nego sustavna teologija.

U središtu Bergogliove kerigmatske teologije njegova je iskustvena istina o Božjem milosrđu. Milosrđe je, naglašava on, »posljednji i najviši čin kojim nam Bog dolazi u susret. Milosrđe: ono je temeljni zakon koji prebiva u srcu svake osobe (... ). Mi-

${ }^{6}$ Pobudnica ima devet poglavlja. Poglavlja 6, 7 i 8 tiču se pastoralnih izazova s dviju sinoda. Tekst donosi 37 navoda s prve, izvanredne sinode, a 53 navoda iz završne relacije s redovne sinode. No ono što je znakovito jest da Papa sastavlja prvo poglavlje - svetopisamsko utemeljenje braka. »Franjin, čini se, još jači i originalniji doprinos jest u središnjim poglavljima pobudnice: četvrtom (posvećenom opisu bračne ljubavi) i petom (o plodnosti). Puno koristi svoje kateheze o obitelji (...). I posljednje poglavlje posvećeno obiteljskoj duhovnosti posreduje Papine misli i sugestije $\ll(\mathrm{M}$. OMETTO, Divorziati che vivono una nuova unione nella Chiesa cattolica, 244.).

${ }^{7}$ U AL, u VII. poglavlju, Pojačati odgoj djece, u kontekstu govora o obitelji koja odgaja i koja postaje »subjektom pastoralnog djelovanja time što izrijekom naviješta evanđelje i što baštini razne vrste svjedočenja «, Papa piše: »U svim obiteljima također treba odjekivati kerygma, u dobrim i lošim vremenima, da nas prosvjetljuje na našem putu. Svaki bi od nas trebao moći reći, na temelju iskustva doživljenog u obitelji: 'I mi smo upoznali ljubav koju Bog ima prema nama i povjerovali joj' (1 Iv 4,16). Samo polazeći od toga iskustva, obiteljski će pastoral moći postići to da obitelji budu istodobno kućne Crkve i evangelizacijski kvasac u društvu « (br. 290).

Vrijedan članak o odgoju djece na temelju pobudnice AL: D. FARES, Educare i figli secondo Amoris laetitia, u: FRANCESCO, Amoris laetitia, 257-267. 
losrđe: ono je put koji sjedinjuje Boga i čovjeka, jer otvara srce nadi da smo ljubljeni zauvijek usprkos ograničenju zbog svoga grijeha $\ll^{8}$.

U poimanju Crkve, što je presudno za razumijevanje pobudnice Amoris laetitia ${ }^{9}$, osim važnosti krajevnih Crkava, što smo ranije istaknuli, Papa nastavlja - u kontinuitetu - na koncilsku ekleziologiju. On je u njoj odgajan i obrazovan. Riječ je najprije o ekleziologiji zajedništva (communio), i to onoga pučkoga, lokalnoga, obiteljskoga i župnoga zajedništva Božjega naroda koji hodočasti, kako to obrazlaže koncilska dogmatska konstitucija o Crkvi Lumen gentium. Bergoglio je teolog naroda, bolje kazano, puka, gdje se puk (narod) ne razumijeva kao politička kategorija demosa i etnosa, građanstva i nacije, nego kao Božji narod, kao korporativna osobnost koja za svoje postupke, za molitve i štovanje Boga, za izbor poglavara, za odnos prema bližnjima i strancima odgovora izravno Bogu. ${ }^{10}$ Papa Franjo crkveno hodočasničko zajedništvo često preriče u gostoljubivu Crkvu uvijek otvorenih vrata.

Osim Crkve Božjega hodočasničkoga puka, u ekleziologiji Papa ide i korak dalje, uvijek nastavljajući u koncilskom duhu. Tako ekleziologiju koncilske pastoralne konstitucije o Crkvi u suvremenom svijetu Gaudium et spes, naime sliku Crkve koja dijeli sa suvremenicima njihovu sudbinu, koja dijalogizira i služi čovjeku i svijetu, preriče u Crkvu izlaska ljudima, svim ljudima, s preferencijom za one na društvenim periferijama, prema Amoris laetitia, svojoj »najslabijoj « djeci u braku i obitelji, »obilježenima izgubljenom i ranjenom ljubavlju «, dakle ne samo materijalno siromašnima nego i onima na egzistencijalnim periferijama, sve dotle da Crkva oplijeni sebe u svome bogatstvu i raskoši, moći i udobnosti, da se čak liši svojih prava i privilegija te da postane jedna vrsta $\gg$ poljske bolnice $\ll{ }^{11}$.

Papa Franjo ima i nekoliko nosivih životnih načela, postulata, kojima se vodi u teološkoj prosudbi društva i za ostvarenje općega dobra i socijalnoga mira. Naveo ih je u programskoj pobudnici Evangelii gaudium (217-237) ${ }^{12}$ : 1) Vrijeme je više

${ }^{8}$ FRANJO, Misericordiae vultus. /Lice milosrda/, Bula najave izvanrednoga jubileja milosrđa, Zagreb, 2015., br. 2.

${ }^{9}$ Usp. H. J. POTTMEYER, Volk Gottes auf dem Weg. Die Kirchenverständnis von Papst Franziskus als Schlüssel zu Amoris laetitia, u: S. GOERTZ, C. WITTING (ur.), Amoris laetitia - Wendepunkt für die Moraltheolgie, Freiburg im Breisgau, 2016., 323-332.

${ }^{10}$ Usp. E. C. BIANCHI, Introduzione alla teologia del popolo. Profilo spirituale di Rafael Tello, Bologna, 2015. Predgovor toj knjizi napisao je Jorge Maria Bergoglio, tada nadbiskup Buenos Airesa (10. svibnja 2012.).

${ }^{11}$ Usp. AL, br. 291.

${ }^{12}$ Kratka pojašnjenja o svakom načelu nalaze se u: N. CAPPELLETTO, I »prinicipi-guida « di papa Francesco, u: G. Del MISSIER, A. G. FIDALGO (ur.), Amoris laetitia. Il Vangelo dell'Amore: un cammino da intraprendere..., Padova, 2018., 81-91. 
od prostora, 2) Jedinstvo prevladava konflikt, 3) Stvarnost je važnija od ideje i 4) Cjelina je viša od dijela. ${ }^{13}$ Prvo načelo o prednosti vremena nad prostorom navodi i u Amoris laetitia, u kontekstu odgoja i nekih loših odgojnih mjera poput pretjerane brige i kontrole roditelja te neuvažavanja odgoja kao procesa. Papa smatra da je $\gg$ važnije otpočinjati procese nego dominirati prostorima $\ll .{ }^{14} \mathrm{U}$ središtu pastoralnoga rada crkvenih pastira stoji ugledanje u Božju postupnu pedagogiju i njegovo milosrđe pokazano u Isusu Kristu prema svim ljudima. Proces je to samoodgoja i odgoja u vjeri, kroz savjest i zajednički život u obitelji, župnoj zajednici i društvu, ali uvijek pred milosrdnim Božjim licem.

\section{Pastoral braka i obitelji prema Amoris laetitia}

Ako bismo u najkraćem htjeli sažeti pastoralne smjernice koje proizlaze iz Amoris laetitia, onda bi to bio poziv da se iznova preispita i obnovi ono najvažnije - ljubav, put ljubavi u obitelji - via caritatis, u pripremi za ženidbu, u već postojećim bračnim i obiteljskim odnosima, posebno u onim nesavršenim, te da se u Crkvi obnovi pastoral braka i obitelji također pod aspektom Božje milosrdne ljubavi. ${ }^{15} \mathrm{U}$ pobudnici se dakle sve vrti oko Božje ljubavi i milosrđa i uvijek se iznova vraća njima kao izvoru i nastanku, kriteriju zajedničkoga života, zadnjem horizontu i cilju svega. U tom smislu možda je i za pastoral pripreme za brak, i za pastoral obitelji, i uopće za

${ }^{13}$ U izvorniku stoji: »Il tempo è superiore allo spazio, L'unità prevale sul conflitto, La realtà è più importante dell'idea, Il tutto è superiore alla parte $\ll$.

${ }^{14} \gg$ Ako je jedan roditelj opsjednut time da u svakom trenutku mora znati gdje mu je dijete i kontrolirati sva njegova kretanja, time će nastojati samo zavladati njegovim prostorom. No tako neće odgajati, jačati i pripremati svoje dijete na suočavanje s izazovima. Ono što je najvažnije jest potaknuti u djetetu, s puno ljubavi, procese rasta u slobodi, zrelosti, cjelovitom razvoju i njegovanju autentične autonomije. ( ... Pravo pitanje, dakle, nije gdje je naše dijete fizički, s kim je u ovom trenutku, nego gdje je u egzistencijalnom smislu, gdje se nalazi sa stajališta svojih uvjerenja, ciljeva, želja i životnih planova « (AL, br. 261), izričit je Papa.

${ }^{15}$ Broj AL 306, u kojem se govori o kršćanskom putu ljubavi, s pravom se može nazvati draguljem pobudnice. Po svetopisamskim navodima te naglasku na ljubavi i milosrđu možemo zaključiti i da je to ponajviše tekst pape Franje. Evo teksta cijeloga broja: »U svakom slučaju, kad je riječ o onima koji imaju teškoće u življenju Božjega zakona u potpunosti, mora se jasno čuti poziv da slijede via caritatis. Bratska je ljubav prvi zakon kršćanâ (usp. Iv 15,12; Gal 5,14). Ne zaboravimo biblijsko obećanje: 'Prije svega imajte žarku ljubav jedni prema drugima jer ljubav pokriva mnoštvo grijeha!?' (1 Pt $4,8)$; 'iskupi svoje grijehe pravednim djelima i svoja bezakonja milosrđem prema siromasima' (Dn 4,24). 'Kao što voda gasi uzbuktali oganj, tako i milosrđe čisti od grijeha' (Sir 3,30). To je i ono što uči sveti Augustin: 'Kao što kada zaprijeti požar trčimo tražiti vodu da ga ugasimo, (...) isto tako, ako iskra grijeha plane iz naše slame i zbog toga se u nama javi nemir, netom nam se ukaže zgoda da učinimo neko djelo milosrđa, veselimo se tome djelu kao izvoru koji nam se pruža da ugasimo požar'« (AL, br. 306). Usp. također T. KRAFFT, Liebe in postsäkularen Zeiten, u: G. AUGUSTIN, I. PROFT (ur.), Zum Gelingen von Ehe und Familie, 385. 
pastoral zajedništva najrječitije i najkorisnije IV. poglavlje pobudnice, u kojem se na svjež način reinterpretira Pavlov himan ljubavi iz poslanice Korinćanima.

Iako može djelovati, a mnogi tako smatraju, da se pastoral obitelji prema toj pobudnici treba koncentrirati na njezino VIII. poglavlje (AL, br. 291-312), koje je više djelo dviju sinoda nego samoga Pape, i to na one situacije koje Papa nevoljko zove $\gg$ takozvane 'neredovite' $\ll{ }^{16}$, pobudnica je ipak usmjerena na šire pastoralno područje. ${ }^{17}$ Ako bi se čak željelo provocirati, kako piše M. Ometto, pobudnica ništa ne bi izgubila ako bi se VIII. poglavlje i ispustilo, iako je ono najčitanije, najviše osporavano i najkomentiranije, jer je u bitnome sve već kazano u prijašnjim poglavljima. ${ }^{18}$

Teološka definicija kršćanskoga braka donosi se nigdje drugdje nego baš na početku toga VIII. poglavlja. Njome se sažeto pokazuje što je bila preokupacija dviju sinoda i sada čitave pobudnice. Definicija ne donosi novi nauk o braku, nego potvrđuje kontinuitet crkvenoga naučavanja, uz uvažavanje sinodalnosti ${ }^{19}$, kolegijaliteta biskupa, sinodskih otaca, i njihova pastoralnoga iskustva. Naglašava se također, da ne bi bilo zabune, da postoje razni oblici zajedništva [unione], ne braka! Neki su posve suprotni crkvenom sakramentu, a neki od njih imaju određene konstruktivne elemente. Evo te definicije:

$\gg$ Kršćanski brak, kao odraz sjedinjenja između Krista i njegove Crkve, u potpunosti se ostvaruje u sjedinjenju muškarca i žene, koji se daju jedno drugom u isključivoj ljubavi i slobodnoj vjernosti, koji pripadaju jedno

\footnotetext{
${ }^{16}$ Terminom neredovite situacije pobudnica se koristi samo nužno u vezi s nerazrješivosti ženidbe (usp. AL, br. 296, 297, 298, 301, 305, 307). Radije se koristi izrazima nesavršen način sudjelovanja u životu Crkve (AL, br. 78), nepotpun način (AL, br. 291), koji ne odgovara nauku Crkve (AL, br. 292), različite situacije slabosti / krhkosti i nesavršenosti (AL, br. 296) (usp. M. OMETTO, Divorziati che vivono una nuova unione nella Chiesa cattolica, 251.).

${ }^{17}$ Pobudnica je vrlo bogata sadržajem. Ima devet poglavlja. Sam Papa u broju AL 6 objašnjava sadržaj pobudnice: »Tekst započinje poglavljem nadahnutim Svetim pismom [U svjetlu Riječi], koji daje odgovarajući ton. Polazeći od toga promatrat ću današnje stanje obitelji [Stvarnost i izazovi obiteljî], kako bismo bili čvrsto utemeljeni u stvarnosti. Podsjetit ću zatim na neke bitne vidove crkvenog učenja o braku i obitelji [Pogled upravljen Isusu: Poziv obitelji], čime se utire put dvama središnjim poglavljima posvećenim ljubavi [Ljubav u braku, Ljubav koja postaje plodna]. U nastavku ću istaknuti neke pastoralne pristupe [Neke pastoralne perspektive] koji nas mogu usmjeravati u izgrađivanju čvrstih i plodnih obitelji u skladu s Božjim naumom a jedno poglavlje posvetit ću odgoju djece. Zatim ću uputiti poziv na milosrđe i pastoralno razlučivanje onih stanja koja ne odgovaraju potpuno onome što Gospodin traži od nas [Pratiti, razlučivati i integrirati slabosti] te, na kraju, zaključiti kratkim crtama o obiteljskoj duhovnosti [Bračna i obiteljska duhovnost].«

${ }^{18}$ M. OMETTO, Divorziati che vivono una nuova unione nella Chiesa cattolica, 254.

${ }^{19}$ Usp. J. SCHUSTER, Auf dem Weg zu einer neuen Gestaltung des päpstlichen Lehramtes? Amoris laetitia und si Sinodalität der Kirche, u: S. GOERTZ, C. WITTING (ur.), Amoris laetitia - Wendepunkt für die Moraltheolgie, 224-248.
} 
drugom do smrti i koji se otvaraju prenošenju života, a posvećeni su sakramentom koji im daje milost da postanu kućna Crkva i kvasac novog života za društvo. Drugi oblici zajedništva u dubokoj su opreci s tim idealom, dok druge [treba drugi, misli se na oblici zajedništva - prim. I. Š.] to ostvaruju bar na djelomičan i sličan način. Sinodski su oci naveli da Crkva ne propušta vrednovati konstruktivne elemente u onim situacijama koje još uvijek ili više ne odgovaraju njezinu učenju o ženidbi $\ll^{20}$.

Uzimajući pobudnicu u cjelini, uočava se dakle da je njezino središte ljubav muškarca i žene, i to poticaj (pobudnica) na ljubav po uzoru na Božju ljubav u Kristu. Nije riječ ponajprije o doktrini ili moralnom učenju o braku ${ }^{21}$, nego je ljubav središte oko kojega se strukturira čitav dokument, pojedina poglavlja i brojevi. I famozno VIII. poglavlje, koje govori o drugim oblicima zajedništva [unione], može se razumjeti ne samo u kontekstu konstruktivnih elemenata tih nesavršenih (nepotpunih) oblika zajedništva muškarca i žene nego prije svega u kontekstu milosrđa, vrhunca Božje ljubavi prema nama ljudima, kao »poziv na milosrđe i na pastoralno razlučivanje onih stanja koja ne odgovaraju potpuno onome što Gospodin traži od nas $\ll^{22}$.

Amoris laetitia, pobudnica o ljubavi u obitelji, pastoralno je usmjerena. ${ }^{23}$ Papa međutim ne poziva samo na promjenu pastoralne prakse nego i na sami način postojanja ili identiteta Crkve, što je još širi zahtjev. Pitanje ekleziologije, pastoralne ekleziologije, nedvojbeno je ono čime Papa najviše stvara nemir u Katoličkoj Crkvi. U svakom slučaju »pastoralni《 ne znači nešto sekundarno, kao što se voli reći »ovo

\footnotetext{
${ }^{20}$ AL, br. 292.

${ }^{21}$ Usp. isto, br. 311.

${ }^{22}$ Isto, br. 6.

${ }^{23}$ Njemačka biskupska konferencija izdala je priopćenje 23. 1. 2017. u kojem se osvrnula na pobudnicu Amoris laetitia: »Die Freude der Liebe, die in den Familien gelebt wird, ist auch Freude der Kirche «. Einladung zu einer erneuerten Ehe- und Familienpastoral im Licht von Amoris laetitia. Njemackki biskupi naglašavaju da obnovljeni bračni i obiteljski pastoral prema pobudnici stavlja naglasak na IV. poglavlje. Pismo inzistira na četiri težišne točke: 1) Priprema za brak - jedna vrsta bračnoga katekumenata u kojem sudjeluje čitava zajednica (usp. AL, br. 206); već postoje razni modeli pripreme na dijecezanskoj i naddijecezanskoj razini; 2) Osnaženje praćenja i savjetovanja brakova u teškim situacijama (usp. AL, br. 49); osnaženje odluke za brak (usp. AL, br. 35); šansa ekumenskoga dijaloga; 3) Osnaženje obitelj kao mjesta gdje se uči vjera; obitelj je škola vjere i posredovanja vjere (usp. AL, br. 287); roditelji su Božje oruđe za zrenje i razvoj djece (usp. isto); 4) Ophođenje s lomnostima (Zerbrechlichkeit): pratiti - razlučivati - uključiti. Tomu pismo posvećuje najviše pozornosti. Navodi razloge nevolja u kojima su najviše pogođena djeca; treba biti blizu i dati prednost milosti (usp. AL, br. 37). Naglašava nerazrješivost braka. Nitko ne može zauvijek biti isključen, nego svi pripadaju Crkvi (usp. AL, br. 299). Posebno važnost razlučivanja u iregularnim situacijama i mogućnost pristupa sakramentima (usp. AL, br. 300 i 305). »Ne mogu svi vjernici čiji je brak razrušen i koji su civilno razvedeni i ponovno vjenčani, primiti sakramente. $\ll$ Traže se diferencirana rješenja.
} 
je samo pastoralna, a ne doktrinarna promjena «. Riječ je dakle ne samo o promjeni pastoralne paradigme nego o novoj pastoralnoj koncepciji Crkve. ${ }^{24}$ Ako to imamo na umu, onda nije isključeno da osporavanja i protivljenja toj pobudnici više dolaze zbog zahtjeva promjene pastoralne prakse koji se postavljaju pred biskupe i svećenike nego pred same supružnike i obitelji.

Papi je svaki pastoral biblijski utemeljen. Zato se u pobudnici traži da se oni koji se spremaju ući u brak upoznaju sa Svetim pismom, s Božjom riječi (usp. posebno I. poglavlje: $U$ svjetlu Riječi). U vremenu promijenjenih antropološko-kulturnih postavki o braku i obitelji kao provizoriju, u vremenu pretjeranoga individualiz$\mathrm{ma}^{25}$, celibaterskoga mentaliteta, straha od samoće i istodobno straha od gubitka slobode i zarobljenosti odnosima ${ }^{26}$, pobudnica traži pripravu mladih ljudi za brak - za zajednički život. Pobudnica također zahtijeva od pastoralnih radnika praćenje mladih bračnih parova u njihovim prvim godinama braka. Pritom se naglašava da se »teološki ideal braka « ne bi trebao predstavljati na »apstraktan način « jer s pretjeranim idealiziranjem djeluje kao da je brak »umjetna tvorevina «, nego da bi trebalo »poticati povjerenje u Božju milost « kako bi se više nego teret brak smatrao privlačnim i poželjnim ${ }^{27}$. I ovdje, kao i u drugim spisima i govorima, papa Franjo polazi od ljudske nesvršenosti i postupnosti u nasljedovanju Božje milosti.

Cjelokupni ton pobudnice Amoris laetitia odiše pozivom na uzvišenost braka i bračne ljubavi, na radost i ljepotu obiteljskoga života, pozivom na povjerenje u Boga, ali i povjerenje u čovjeka, nesavršena čovjeka, koji je uza sva svoja ograničenja i slabosti sposoban na slobodu odluke za bračni i obiteljski život pomoću Božjega milosrđa. Nitko brak i obitelj ne bi smio doživljavati kao »teret koji treba podnositi cijeli život « niti se osjećati neslobodnim i zarobljenim. Smatramo da je ta pobudnica izazvala nemire dijelom i zbog toga što u pastoralu poziva na osobnu slobodu kroz odgoj savjesti prema evanđelju, na ponovno vrjednovanje savjesti u životu pojedinca i $\mathrm{Crkve}^{28}$, na samostalno odlučivanje iz vjere, na osobno odgovor-

${ }^{24}$ Usp. J. F. KEENAN, Amoris laetitia, 43. Keenan tvrdi da je II. vatikanski koncil bio pastoralan, kao i da papa Franjo provodi pastoralne reforme u duhu II. vatikanskoga koncila i vodi Crkvu svojim pastoralnim poučavanjem. O različitim čitanjima pobudnice također usp. E. SCHOCKENHOFF, Traditionsbruch oder notwendige Weiterbildung? Zwei Lesarten des Nachsynodalen Schreibens Amoris laetitia, u: G. AUGUSTIN, I. PROFT (ur.), Zum Gelingen von Ehe und Familie, 282-296.

${ }^{25}$ Usp. AL, br. $32-33$.

${ }^{26}$ Usp. isto, br. 34.

${ }^{27}$ Usp. isto, br. 36.

${ }^{28}$ Usp. L. MARTÍNEZ SISTACH, Come applicare l'Amoris laetitia, 2016., 71. Prema tom autoru Papa slijedi konstituciju GS, br. 16: savjest je nucleus secretissimus atque sacrarium hominis. Ističe kako se malo govori o savjesti te da je potreban pastoral savjesti što papa Franjo čini tim dokumentom (29 puta se u AL spominje termin savjest). 
no djelovanje, a ne da se s gotovim normama odozgo pristupa ljudskim odnosima, pogotovo onim najdelikatnijim, kakvi su bračni i obiteljski. Pobudnica jasno kaže: »Mučimo se također dati prostor savjesti vjernikâ, koji usred svojih ograničenosti vrlo često odgovaraju što je bolje moguće na evanđelje, te su sposobni ostvariti svoje vlastito razlučivanje u složenim okolnostima. Pozvani smo odgajati savjesti, a ne težiti tome da ih zamijenimo $\ll^{29}$.

Moralni teolog J. F. Keenan govori da pobudnica ponavlja ono što je već Koncil kazao, naime primat savjesti potvrđuje i nauk konstitucije Gaudium et spes. Za papu Franju, sljedbenika ignacijanske duhovnosti ispita savjesti, ispravna savjest uključuje krjepost poniznosti. Grižnja savjesti znak je skrušenosti pred Bogom. Imati savjest znači spoznati i priznati vlastitu krivicu, pomaže nam shvatiti objektivnu moralnu istinu. Kada pak otkrijemo svoju grješnost, otkrivamo i slobodu da smo mogli djelovati drukčije, bolje, a ne samo da smo slabi i prisiljeni postupati prema nekom determinizmu. Savjest je ključ za naše odnose sa sobom, s drugima, s Bogom. ${ }^{30}$

Pobudnica ne govori o preljubu, o grijehu i grješnosti, nego o slabostima, fragilnosti i nesavršenostima. Neki autori argumentirano prigovaraju da je u tom dokumentu grijeh olako sveden na slabost. Prema oštroj kritici G. Meiattinija pobudnica ne govori ni o sakramentalnom značenju braka (iako spominje Krista i Crkvu). ${ }^{31}$

${ }^{29}$ AL, br. 37.

${ }^{30}$ Usp. J. F. KEENAN, Amoris laetitia, 52-56. Vrijedan članak o savjesti u pobudnici AL i vezi s koncilskim naukom usp. A. AUTIERO, Amoris laetitia und das sittliche Gewissen. Eine Frage der Perspektive, u: S. GOERTZ, C. WITTING (ur.), Amoris laetitia - Wendepunkt für die Moraltheolgie, 95-113.

${ }^{31}$ G. Meiattini, talijanski benediktinac, kritičan prema II. vatikanskom koncilu i njegovoj pastoralnoj usmjerenosti, napisao je i knjigu kritike na VIII. poglavlje AL. Njegova se kritika svodi na isključenje sakramentalnosti u govoru o braku i obitelji, na svođenje sakramenata na moral, ali i na neimenovanje stvari kakve jesu, na teške Papine lingvističke omaške. Taj autor utvrđuje da nema temeljnoga svetopisamskoga i tradicijskoga pojma preljub u pobudnici. Preferira se govoriti o $\gg$ situacijama slabosti ili nesavršenosti (AL, br. 296ss) umjesto korištenja pojmom grijeha. VIII. poglavlje govori kako treba »pratiti, razlučivati i integrirati slabosti «, a ne kako se suočiti s grijehom. U izvorniku stoji fragilità, u hrvatskom izdanju pobudnice prevedeno je riječju slabost (debolezza) i značilo bi i krhkost, lomnost koja ne nastaje iz moralne zloće subjekta, nego je to po naravi. U svakom slučaju, smatra Meiattini, slabost, nesavršenost i krhkost pripadaju stvorenju kao takvomu i zahtijevaju brižnost, skrb, dok je grijeh gubitak integriteta; »slabost i nesavršenost mogu supostojati sa supstancijalnom dobrotom moralnih čina, grijeh je naprotiv djelomični ili potpuni gubitak dobrote «. I nastavlja: »Nasloviti 'slabostima' poglavlje koje obrađuje kršenje integriteta bračnoga veza, nije korektan leksički izbor. Slabost, kao i nesavršenost, nije krivnja onoga koji traži oproštenje, nego više stanje predgrešno i izvangrešno, da se razumijemo. Stoga, slabosti mogu biti integrirane, grijeh ne! (G. MEIATTINI, Amoris laetitia? I sacramenti ridotti a morale, Torino, 2018., 44-45.).

Drukčije od Meiattinija razmišlja moralni teolog Autiero. On govori o konvergenciji pastoralne i moralne teologije jer su kao teologija po sebi znanost o životu. Posebna mjesta njihove konvergen- 
Bergogliova antropologija ne inzistira na grijehu koliko na ranama ${ }^{32}$ i slabostima, lomnosti i krhkosti (fragilità) te na Božjem milosrđu koje poziva na novi život, na postupno, ali neodgodivo obraćenje.

\subsection{Metodologija I SUbJEKTI PASTORAla BRAKA}

Već se na sinodama iskristalizirala metodologija pastorala braka i obitelji, pogotovo pri kritičnim situacijama, koja je kasnije ušla u dokument Amoris laetitia. Riječ je o pastoralnom putu, procesu koji označuju tri glagola: pratiti - razlučivati - integrirati. ${ }^{33}$ Ta je metoda slična, ali nije ista metodi koncilske konstitucije Gaudium et spes, kao i metodi dokumenata iz Medelina i Pueble, dijelom i metodi teologije oslobođenja, poznatoj kao metodi: vidjeti - prosuditi - djelovati. Pratiti je različito od vidjeti jer zahtijeva »uplitanje «, unošenje i uživljavanje u situaciju drugoga, dok se vidjeti može s neutralne udaljenosti. Vjerojatno jezično najljepše, pastoralnoteološki najbogatije o značenju pastoralne pratnje u toj pobudnici iskazano je u sljedećim riječima:

>Premda uvijek vjernicima preporučuje savršenstvo i poziva na potpuniji odgovor Bogu, Crkva mora brižno i pažljivo pratiti svoju najslabiju djecu, obilježenu izgubljenom i ranjenom ljubavlju, vraćajući povjerenje i nadu poput svjetionika neke luke i baklje koja se nosi među ljude da prosvijetli one koji su skrenuli s pravoga puta ili se nalaze usred oluje. $\mathrm{Ne}$ zaboravimo da je često rad Crkve nalik onom u poljskoj bolnici $\ll^{34}$.

Razlučivati je više od prosudbe, ili bi barem trebalo biti. Središnji je termin pobudnice i njemu ćemo posvetiti više pozornosti. Znamo da je taj pojam svojstven sv. Pavlu. On naime govori o razlučivanju duhova (diakriseis pneumatôn) kao osobitom daru Duha Svetoga (1 Kor 12, 10). U pobudnici se govori o razlučivanju Božje volje i dobra bližnjih. I kao što postoje lažni i istinski proroci, lažni i istinski svećenici, biskupi, teolozi i teško ih je razlikovati, tako postoje dobri i opaki duhovi, Bož-

cije jesu zajednica vjernika (sensus fidelium), iskustvo vjere, kao i povijesnost (vremenost). Njihova je posebna veza u razlučivanju: pastoralnom (EG, br. 33; AL, br. 312) i evanđeoskom (EG, br. 50). Riječ je o pastoralno usmjerenoj moralnoj teologiji (usp. A. AUTIERO, Amoris laetitia. Tra teologia pastorale e teologia morale, u: ISTI (ur.), Per una nuova cultura pastorale, 23-39.).

32 Usp. P. M. ZULEHNER, Il cambiamento nella cultura pastorale di Papa Francesco. Un'analisi dei suoi testi pastorali, u: A. AUTIERO (ur.), Per una nuova cultura pastorale, 17-22. Zulehner naglašava da ovaj papa ne polazi od grijeha i čovjekove grješnosti, nego od rana; Crkva nije sudačka dvorana, nego poljska bolnica te umjesto moraliziranja ozdravlja; Papa nije ideolog, nego pastir.

${ }^{33}$ Usp. M. OMETTO, Divorziati che vivono una nuova unione nella Chiesa cattolica, 240.

${ }^{34}$ AL, br. 291. 
je dobre sile i demoni i zlodusi, a i njih je teško razlikovati. Razlučivanje duhova, okolnosti i odgovornosti pojedinih osoba uistinu je izniman Božji dar. ${ }^{35}$

Uz rečeno, odnosno zajedno i usporedno s praćenjem i razlučivanjem, prema pobudnici, u pastoralnom radu traje integracija u zajednicu, pomoć da se krhki i slabi ljudi osjete dobrodošlim članovima zajednice, braća i sestre Kristove Crkve.

S obzirom na subjekte pastorala, u VI. poglavlju pobudnice, naslovljenom Neke pastoralne perspektive, naglašava se da su obitelji »nositeljice obiteljskoga pastorala « te da su prve pozvane naviještati $\gg$ evanđelje o obitelji (evanđelje obitelji). Zatim se kaže da je Crkva pozvana da u poniznosti evangelizacijski i katehetski radi s obiteljima, poput evanđeoskoga sijača koji sije svoju riječ, svoju dobrotu ${ }^{36} . \gg$ Obiteljski pastoral 'mora pomoći ljudima da iskuse da je evanđelje obitelji odgovor na najdublja očekivanja osobe: na njezino dostojanstvo i puno ostvarenje u uzajamnosti i zajedništvu. Ne treba samo predočavati pravila nego i predlagati vrednote $(. . .)^{\prime} \ll{ }^{37}$. $\gg$ Glavni doprinos obiteljskom pastoralu $\ll$ - nastavlja pobudnica - »pruža župa kao obitelj obiteljî, koja usklađuje doprinose malih crkvenih zajednica, pokreta i udruga $\ll^{38}$. U dokumentu se traži prikladnija naobrazba svećenika, đakona, redovnika i redovnica, vjeroučitelja i ostalih pastoralnih radnika za pastoral obitelji. Utvrđuje se neprikladna izgradnja zaređenih služitelja za bavljenje složenim obiteljskim problemima i predlaže se iskustvo istočne tradicije oženjenih svećenika ${ }^{39}$. Posebno to vrijedi za odgoj bogoslova (za njihovu zrelost i psihičku ravnotežu), jer >obiteljske veze imaju temeljnu važnost za jačanje zdravog samopoštovanja sjemeništaraca i bogoslova «, pa je, prema pobudnici, nužna uključenost laika i obitelji, a posebno žena u svećeničkoj izgradnji ${ }^{40}$.

Papa poziva na pastoralnu samokritiku, posebno na odbacivanje pelagijanizma, koji može odvratiti od puta realnosti. ${ }^{41}$ Prije nego denunciramo grješna stanja, nužno

${ }^{35} \mathrm{O}$ razlučivanju, čišćenju i obnovi usp. EG, br. 30. U 1 Iv 4 , 1 govori se o ispitivanju duhova (dokimazete ta pneumata - provjeravajte duhove). Ovomu je Papi, odgojenom na isusovačkoj duhovnosti, posebno važno razlučivanje. O pojmu razlučivanja kod pape Franje usp. A. SPADARO, L. J. CAMELI, La sfida del discernimento in Amoris laetitia, u: FRANCESCO, Amoris laetitia, 242-256.

${ }^{36}$ Usp. AL, br. 200.

${ }^{37}$ Isto, br. 201.

${ }^{38}$ Isto, br. 202.

${ }^{39}$ Usp. isto.

${ }^{40}$ Usp. isto, br. 203.

${ }^{41}$ To posebno ističe bečki kardinal Schönborn (usp. A. SPADARO, Conversazione con il cardinale Schönborn sull'Amoris laetitia, u: FRANCESCO, Amoris laetitia, 205.). A o mračnoj duhovnoj svjetovnosti, gnosticizmu, autoreferencijalnom i prometejskom neopelagijanizmu usp. Papine pobudnice: Evangelii gaudium, br. 93-97; Gaudete et exsultate, br. 47-48. 
je navijestiti i pratiti, stimulirati rast i konsolidirati ljubav, onaj pozitivni impuls za činjenje dobra. Ključ čitanja toga dokumenta nije dakle put potrage za grijehom ni put sebeobrane, na kojem smo opsjednuti tuđim zlom i svojom ispravnošću, sablažnjavanjem nad tuđim grijehom i sljepoćom prema sebi, nego vjera u Božje bezuvjetno milosrđe, neusporediva atraktivnost dobra, biblijski realizam ${ }^{42}$ te praksa Dobroga Pastira koji traži izgubljene, što nipošto ne znači odricanje od uzvišenosti ideala ${ }^{43}$.

Iako se govori u terminima vođenja, pastoral braka i obitelji prema pobudnici nije u striktnom i dirigiranom upravljanju ljudima, nego u savjetovanju i praćenju, ponajprije zaručnika na putu priprave za ženidbu ${ }^{44}$. Mladim ljudima treba $\gg$ pomoći otkriti dostojanstvo i ljepotu braka $\ll$ i privlačnost potpunoga sjedinjenja $\ll{ }^{45}$. U pripremi za brak ne sudjeluju samo svećenici, župnici, nego je potreba »većeg uključivanja čitave zajednice, dajući povlašteno mjesto svjedočenju samih obitelji, kao i ukorjenjivanju priprave za ženidbu u hod kršćanske inicijacije, ističući povezanost ženidbe $s$ krštenjem i ostalim sakramentima $\ll{ }^{46}$.

Pobudnica potom zahtijeva i »posebne programe za bližu pripravu za ženidbu, koji će pružiti pravo iskustvo sudjelovanja u crkvenom životu i produbiti različite vidove obiteljskog života $\ll{ }^{47}$. Ističe se da je $\gg$ praćenje zaručnika u njihovu rastu u ljubavi blagodat za njih same $\ll{ }^{48}$. Postoje prigovori da se brak i obitelj svode na pojedince, na savjesti i na foro interno. Pobudnica izrijekom naglašava važnost zajednice i stalno ističe da je sakrament ženidbe sakrament ne samo dvoje ljudi nego čitave kršćanske zajednice, ponajprije župe. ${ }^{49}$

Za pastoral braka i obitelji unutar kršćanske zajednice preporučuju se tzv. misionarski aktivne obitelji ${ }^{50}$. Riječ je o posebno zauzetim supružnicima, roditeljima koji se

\footnotetext{
${ }^{42}$ Usp. AL, br. 211.

${ }^{43}$ Usp. isto, br. 307.

${ }^{44}$ Usp. isto, br. 204.

${ }^{45}$ Isto, br. 205. Uz razlučivanje ovaj papa naglašava izgradnju i vježbanje u krjepostima (dominikansko-tomistički put). Ovdje je riječ posebno o krjeposti čistoće (usp. AL, br. 206).

${ }^{46}$ AL, br. 206.

${ }^{47}$ Isto.

${ }^{48}$ Isto, br. 207.

${ }^{49}$ Neke su se pojedinosti izmijenile. Sjetimo se u tom kontekstu da je sve donedavno bilo javno naviještanje ženidbe na misnom slavlju, i to po tri nedjelje uzastopno (danas jednom), da bi se ostavila mogućnost da zajednica kaže svoje mišljenje o prikladnosti naviještenih za brak. Koliko god je sakrament ženidbe eminentno sakrament koji podjeljuju dvoje ljudi jedno drugomu, on je i sakrament čitave zajednice.
}

${ }^{50}$ Usp. AL, br. 208. 
svojim iskustvom i susretljivošću stavljaju na raspolaganje onima koji kane stupiti u brak ili su mladi u braku. Pobudnica smatra kako je posve normalno u kršćanskoj zajednici da se događa ne samo bliža nego i daljnja priprava za brak. Ona počinje još u djetinjstvu u obitelji:

»Naučiti voljeti nekoga nije nešto što se radi na brzu ruku, niti se može naučiti na nekom kratkom tečaju neposredno prije slavlja ženidbe. Priprema za brak, zapravo, počinje od samog rođenja, i to vrijedi za svaki par. Sve ono što su primili iz svojih obitelji trebalo bi ih pripraviti da uče iz vlastita iskustva i osposobiti ih za potpunu i konačnu obvezu. Najbolje pripremljeni za ženidbu vjerojatno su oni koji su od vlastitih roditelja naučili što je kršćanski brak, u kojem su se bezuvjetno opredijelili jedno za drugo i svakog dana obnavljaju tu odluku $\ll^{51}$.

U takvoj, rekli bismo, posve prirodnoj i spontanoj pripremi za brak vrijedni doprinosi dolaze i od pučke pobožnosti i pučkoga pastorala. Kao primjer pobudnica navodi spomendan sv. Valentina, »koji u nekim zemljama bolje iskoriste trgovci nego nekreativni crkveni pastiri $\ll^{52}$. Zanimljivo je da taj dokument nema poteškoća s Danom zaljubljenih, dok ga neki svećenici smatraju posve svjetovnim i nekršćanskim; zabranjuju ga kao i slavlja nekih drugih svjetovnih praznika (Nova godina, Dan žena, Pokladni utorak ...) i na njihovo mjesto uvode čak i pokoru. Gledajući po ovom primjeru slavlja sv. Valentina, pobudnica zagovara kristijanizaciju svjetovnoga i evangelizaciju naravne ljubavi.

Čini nam se važnim istaknuti da Amoris laetitia na nekoliko mjesta govori o važnosti prepoznavanja i odgajanja osobnih želja i osobnih očekivanja, kao i nužnosti njihova priopćavanja za zdrave bračne i obiteljske odnose. Pritom se ne propušta naglasiti da $\gg$ ništa nije promjenjivije, krhkije i nepredvidljivije od želja $\ll{ }^{53}$. Dokument kao bezuvjetno zahtijeva da mladi ljudi u pripremi za brak provjere jesu li jedno za drugo jer je brak iznimno ozbiljna stvar. Priprava je škola samoupoznavanja i izricanja samoga sebe drugomu. Nipošto nije ispravno o bitnim stvarima šutjeti kako bi se tobože izbjegli eventualni sukobi ili neuspjesi. Sve ono bitno što se skriva, prešućuje ili lažno tolerira, kasnije redovito izbije kao uništavajući vulkan ili nepremostiva prepreka za nastavak zajedničkoga života. »Problem je što su u početnoj očaranosti jednoga drugim parovi skloni prikrivanju ili relativiziranju mnogih stvari, izbjegavaju se nesuglasice te problemi tek poslije izbijaju na površinu $\ll^{54}$, izričita

\footnotetext{
${ }^{51}$ Isto.

${ }^{52}$ Usp. isto.

${ }^{53}$ Isto, br. 209.

${ }^{54}$ Isto.
} 
je pobudnica. Zato je važno poticati i pomagati u dobrohotnosti da se zaručnici i bračni parovi jedno drugomu iskreno povjere, izreknu svoje želje i očekivanja, da se istinski upoznaju u pravome svjetlu ${ }^{55}$ pa da onda cjeloživotnu odluku donesu zajedno. Predženidbeni pastoral i služi tomu da zaručnici osnaže svoju ljubav, da se unaprijed uče svladavati probleme i moguće nepredvidive teške situacije ${ }^{56}$.

Nije rijetkost da se svećenici žale da im je teško asistirati sakramentu vjenčanja jer je za mnoge postao puka izvanjska manifestacija. Neki će svećenici čak kazati da im je lakše voditi sprovod nego vjenčanje. Pobudnica Amoris laetitia ne propušta progovoriti i o tome. Vrijeme bliže pripreme i slavlja sakramenta ženidbe ne bi trebalo biti potrošeno do iscrpljenosti i umora u dekoraciju, vanjsku proslavu i materijalna sredstva. Poziva se na krjepost umjerenosti u pripremanju slavlja: $\gg$ Dragi zaručnici, imajte hrabrosti biti drukčiji! Ne dopustite da vas proždre društvo potrošnje i vanjštine! $\ll^{57}$ Skromna i jednostavna proslava, kao izraz snažne ljubavi, liturgijsko slavlje kao $\gg$ duboko osobno iskustvo $\ll{ }^{58}$ i povrh svega privola slobode, ljubavi i vjernosti do kraja života.

Iznimno je važno, stoji u pobudnici, naglasiti mladima da se ne trebaju plašiti riječi »doživotno opredjeljenje $\ll{ }^{59}$ te da baš $\gg$ u kulturi globalne komunikacije $\ll$, u kojoj veliku štetu uzrokuje »poplava neodrživih obećanja «, vrate dostojanstvo vlastitim riječima. $\gg$ Držati danu riječ, vjernost obećanju, nešto je što se ne može kupiti ili prodati. Ne može se silom nametati, ali niti sačuvati bez žrtve $\ll{ }^{60}$.

Bliža priprema za sakrament braka podrazumijeva zajedničko čitanje svetopisamskih tekstova, a posebno zajedničku molitvu zaručnika jedno za drugo, kao i da pred Bogom sami, svatko osobno, izreknu molitvu da ostaju vjerni i velikodušni i da se pred Bogom preispituju. ${ }^{61}$ Pobudnica naglašava kako je prvo Isusovo čudo bilo na svadbi u Kani Galilejskoj. Odatle se zaključuje da je sakrament ženidbe prilika svjedočenja evanđelja svima prisutnima, i onima koji su već u braku, kao i onima koji su se udaljili ili uopće nisu vezani za vjeru i crkvenu zajednicu: »Slavitelj ima prigodu govoriti pred skupom osoba koje slabo sudjeluju u crkvenom životu ili

${ }^{55}$ Usp. isto, br. 210. O važnosti izražavanja i odgoja želja kod odgoja djece, o ignacijanskoj pedagogiji, nemaltretiranju granicama, nego uvažavanju limita u djece, a sve na osnovi pobudnice AL, usp. D. FARES, Educare i figli secondo Amoris laetitia, 268s.

${ }^{56}$ Usp. AL, br. 211.

${ }^{57}$ Isto, br. 212.

${ }^{58}$ Isto, br. 213.

${ }^{59}$ Isto, br. 215.

${ }^{60}$ Isto, br. 214.

${ }^{61} \mathrm{O}$ bližoj pripremi, inicijaciji, kao vrsti bračnoga katekumenata i pratnji zajednice usp. W. KASPER, Die Botschaft von Amoris laetitia. Ein freundlicher Disput, Freiburg-Basel-Wien, 2018., 40s. 
pripadaju drugoj kršćanskoj vjeri ili vjerskoj zajednici. To je dragocjena prigoda za naviještanje Kristova evanđelja $\ll^{62}$. Pastoral ženidbe više je od pastoralne brige za dvoje ljudi, za zaručnike.

\subsection{AKTIVNO SLUŠANJE I SOLIDARNO PRAĆENJE BRAČNIH DRUGOVA}

Iz postavke samoodgoja i formiranja vlastite savjesti proizlazi i vrsta pastorala $\mathrm{u}$ kojem naglasak nije na vođenju, nego na pastoralnom praćenju i savjetovanju. Pri tome je važno znati da je subjekt pastorala sam Gospodin i onaj koga se prati, dakle u ovom slučaju bračni par, a pastoralni radnik, svećenik, župnik, bližnji i župna zajednica pomažu da se ostvari međusobno zajedništvo dvoje ljudi pred Bogom. Praćenje kao dio pastorala braka znači pomoći drugima da upoznaju sebe i svoju ljubav koja ih dovodi do braka (ne puka fizička privlačnost i afektivnost ${ }^{63}$ ). $\gg$ Praćenje omogućuje spoznati i razlučiti različite situacije u kojima se nalaze osobe u svojoj savjesti pred Bogom i omogućuje dati objektivan i prikladan pastoralni odgovor. $\ll^{64}$

Prema Amoris laetitia Crkva nije samo ona koja poučava (magistra) već i majka (mater) koja u nježnosti prati rast i sazrijevanje svoje djece, sluša ih u dijalogu i brižno savjetuje. »U središtu je postavljen život i zadatak Crkve da bude suputnik života, stavljajući se u položaj empatičkog slušanja tako da - pozivajući se na papu Franju - pastir i ovce imaju isti miris. $\ll{ }^{65}$ Nikada dovoljno naglasiti da je aktivno slušanje najvažnija sposobnost za zajednički život, a tako i za pastoral. U školi učimo čitati, pisati, govoriti javno, ali se rijetko gdje učimo slušati. ${ }^{66} \mathrm{Da}$ se bližnjega sasluša i shvati, vrijedi izdvojiti vrijeme, disciplinirati svoje mišljenje i riječi, biti pozoran na riječi i geste bližnjega te uvijek s poštujućim suosjećanjem odnositi se prema njemu. ${ }^{67}$

\footnotetext{
${ }^{62}$ AL, br. 216.

${ }^{63}$ Usp. isto, br. 217.

${ }^{64}$ L. MARTÍNEZ SISTACH, Come applicare l'Amoris laetitia, 73.

${ }^{65}$ G. FACCIN, I discernimenti di casi pastorali, u: G. Del MISSIER, A. G. FIDALGO (ur.), Amoris laetitia, 106.

${ }^{66}$ Pozorno, empatično slušanje koje je sposobno prihvatiti bližnjega u svim njegovim dimenzijama može donijeti velike rezultate (usp. G. CUCCI, La coppia e la sfida del tempo, u: FRANCESCO, Amoris laetitia, 279.).

${ }^{67} \gg$ Izdvojiti vrijeme, kvalitetno vrijeme, i biti spreman strpljivo i pozorno slušati sve što druga osoba želi reći. To zahtijeva samodisciplinu, koja se ne sastoji u tom da ne počnemo govoriti prije nego dođe pravi trenutak. Umjesto da počnemo nuditi mišljenja ili savjete, moramo biti sigurni da smo saslušali sve što druga osoba ima potrebu reći. A da bismo to mogli, potrebno je njegovati unutarnju šutnju, koja omogućuje slušati bez rastresenosti srca i uma: bez užurbanosti, ostaviti po strani svoje vlastite potrebe i brige, stvoriti prostor. Često jedan od suprugâ ne treba rješenje svojih problema, nego jednostavno to da ga se sasluša. Želi osjetiti da postoji netko tko shvaća njegovu bol i muku, njegovo razočaranje, njegov strah, njegovu ljutnju, njegove nade i snove« (AL, br. 137).
} 
U prvim godinama braka iznimno je važno pratiti bračne drugove, kako bi što više produbili svoju odluku i sazreli u svojoj ljubavi. Ženidba se ne može shvatiti kao nešto »zaključeno $<\mathrm{u}$ smislu kako su sva rješenja unaprijed donošena. Vjenčanje $\mathrm{i} \gg \mathrm{da} \ll$ privole tek su početak cjeloživotnoga putovanja; $\gg$ sjedinjenje je stvarno i neopozivo, potvrđeno je i posvećeno sakramentom ženidbe «, pri čemu $\gg$ supružnici na sebe preuzimaju glavnu ulogu, postaju gospodari vlastite povijesti i tvorci jednog projekta koji treba zajednički provoditi u djelo $\ll{ }^{68}$.

Ako se prizna i prihvati vlastita nesavršenost, kao i nesavršenost svoga bračnoga druga, ako se ima na umu mogućnost nastanka neopravdanih visokih očekivanja nad kojima treba bdjeti, onda će se lakše prihvatiti zadaća trajnoga zajedničkoga učenja i sazrijevanja i ne će se događati suvišne razmirice i olaki sukobi za sitnice ni brzoplete odluke za rastavu ${ }^{69}$. U ljudskim odnosima, a povrh svega u braku, nema osvojenih pozicija za sva vremena ni stajanja na istom mjestu. Bračni život uvijek je kretanje. Sastoji se od više etapa. ${ }^{70} \mathrm{U}$ svakoj pak vrijedi nesebično sebedarje, napuštanje trgovačkoga odnosa mjerkanja. Zajednički život uključuje pregorijevanje u svojim prohtjevima, pa čak i opravdanim željama. Uključuje i strpljivu ljubav, mudrost $\gg$ pregovaranja $\ll$ i sporazumijevanja o svemu, tako da se odluke nikada ne donose tajno ni jednostrano ${ }^{71}$. Kao u maloj $\gg$ povijesti spasenja $\ll$, brak je $\gg$ možda najveća misija muškarca i žene u ljubavi pomoći jedno drugome postati više muškarac, odnosno više žena $\ll^{72}$.

Brak nije zatvorena zajednica, narcisoidna simbioza dvoje ljudi, nego se ljubav treba širiti i dalje od bračne zajednice. $\gg U$ pastoralnom radu «, traži pobudnica, »bračne parove treba ohrabrivati da budu velikodušni u prenošenju života $\ll^{73}$. Ovdje se ponavlja nauk o odgovornom roditeljstvu i prirodnim razdobljima, kako su navedeni u dokumentima crkvenoga učiteljstva Humanae vitae ${ }^{74}$, Familiaris consortio i Kate-

\footnotetext{
${ }^{68}$ Isto, br. 218.

${ }^{69}$ Usp. isto, br. 221.

$70 \gg$ S početnog stadija, obilježenoga izrazitim osjećajem privlačnosti, prelazi se na potrebu za drugim kao dijelom vlastitog života. Odatle se prelazi na zadovoljstvo zbog uzajamne pripadnosti, zatim na to da se cijeli život shvaća kao zajednički projekt, na sposobnost da se sreća drugoga stavlja ispred vlastitih potreba, i na radost doživljavanja svoga braka kao onoga što je dobro za društvo « (Isto, br. 220).

${ }^{71}$ Usp. isto.

${ }^{72}$ Isto, br. 221.

${ }^{73}$ Isto, br. 222.

${ }^{74} \mathrm{O}$ nastanku, recepciji i značenju enciklike Humanae vitae pedeset godina nakon objavljivanja usp. M. M. LINTER, Von Humanae vitae bis Amoris laetitia. Die Geschichte einer umstrittenen Lehre, Innsbruck-Wien, 2018.
} 
kizmu Katoličke Crkve. Pokazuje se i tim da sadašnji papa nema nakanu mijenjati dogmatski nauk Crkve, nego je više riječ o promjeni pastoralnih naglasaka.

U prvim godinama braka, u godinama dubljega upoznavanja i vježbanja u zajedničkom životu, u pastoralnom praćenju korisna je prisutnost iskusnih bračnih parova.

>Župa se drži mjestom u kojem se iskusni parovi mogu staviti na raspolaganje mlađim parovima, uz moguće sudjelovanje članova udruga, crkvenih pokreta i novih zajednica. Bračne drugove treba poticati na temeljno stajalište prihvaćanja velikoga dara djece. Potrebno je istaknuti važnost obiteljske duhovnosti, molitve, sudjelovanja na nedjeljnoj euharistiji, poticanje bračnih parova da se radosno sastaju kako bi promicali rast $u$ duhovnom životu i solidarnosti u konkretnim životnim potrebama $\ll^{75}$.

Amoris laetitia s neposustalim oduševljenjem govori o važnosti pozornosti, brige i ljubavi bračnih drugova jednoga za drugo, kao i solidarnosti svih onih koji su s tim ljudima na bilo koji način povezani. Ništa i nitko supružnicima ne smije biti važniji od bračnoga druga. Potrebno je, nastavlja pobudnica, vrijeme za sve što se tiče iskazivanja poštovanja i ljubavi prema svom životnom suputniku: vrijeme za razgovor, za poglede, za zagrljaj, za planiranje budućnosti; to uvijek treba činiti sabrano, brižno, bez užurbanosti ${ }^{76}$.

Solidarnost u vremenu, darivanje vremena drugomu, zacijelo je jedno od najvažnijih djela ljubavi u kulturi brzine, potrošnje i straha za sebe, u vremenu kada se može dijeliti fizički prostor, a da se ljudi istinski ne susreću, kada je smanjena komunikacijska distanca, ali nije povećana stvarna blizina, razumijevanje i ljubav među ljudima. »Pastoralni djelatnici i obiteljske skupine «, stoji u pobudnici, $\gg$ trebale bi pomoći mladim i ranjivim parovima da osmisle te zajedničke trenutke, da budu nazočni jedni za druge, čak i da dijele trenutke tišine koji će ih potaknuti da dožive nazočnost drugog bračnog druga ${ }^{77}$. Tu je presudno važno zajedničko planiranje vremena, dobre zajedničke navike i zajednički rituali ${ }^{78}$.

Ako ljubav vodi dvoje mladih ljudi do sakramenta ženidbe, poslije slavlja toga sakramenta vjere on nosi bračnu i obiteljsku ljubav. Praktična osobna vjera svakoga supružnika oblikuje bračne odnose. $\gg$ Mi pastiri«, traži pobudnica, »moramo ohrabrivati obitelji da rastu u vjeri. Zato je dobro poticati ih na često pristupanje ispovijedi, na duhovno vodstvo i na sudjelovanje u duhovnim obnovama. No ne

\footnotetext{
${ }^{75}$ AL, br. 223.

${ }^{76}$ Usp. isto, br. 224.

${ }^{77}$ Isto.

${ }^{78}$ Usp. isto, br. 225-226.
} 
treba zaboraviti pozivati ih na obiteljsku molitvu tijekom tjedna, jer 'obitelj koja moli, ostaje zajedno' ${ }^{79}$.

\subsection{KRIZE SU PRILIKE ZA JAČANJE MEĐUSOBNE LJUBAVI}

Nema nijednoga odnosa, a pogotovo to nije brak, koji je bez problema. Oni su različiti. Teške poteškoće mogu nastati ako netko od supružnika nije kršten ili ne želi živjeti po vjeri ili stvara probleme drugom supružniku koji prakticira vjeru. Pobudnica ističe da $\gg$ ravnodušnost supruga postaje izvorom boli za drugog bračnog druga $\ll^{80}$ koji želi biti kršćanin. Ipak, i u takvim situacijama taj dokument ne popušta u visokim zahtjevima svetosti za kršćanskoga supružnika:

>Usprkos tomu, moguće je naći neke zajedničke vrednote koje se mogu dijeliti i njegovati s oduševljenjem. U svakom slučaju, pokazujući ljubav prema suprugu koji nije vjernik, darivati mu sreću, ublaživati mu boli i dijeliti život s njim, pravi je put posvećenja. $S$ druge strane, ljubav je uvijek Božji dar, i gdje god se izlijeva, daje osjetiti svoju preobraziteljsku snagu, katkad na tajanstvene načine, čak dotle da 'muž nevjernik posvećen je ženom i žena nevjernica posvećena je mužem vjernikom' (usp. 1 Kor $7,14) \ll^{81}$.

Budući da su prve godine braka vrlo delikatne, pobudnica traži od župne zajednice i drugih crkvenih pokreta, udruga i ustanova da budu potpora mladim obiteljima:

»Primjerice, to može uključivati susrete parova koji žive u istom susjedstvu ili se druže, kratke duhovne obnove za suprugê, stručna predavanja o konkretnim pitanjima iz obiteljskog života, bračna savjetovališta, misijske djelatnike pripremljene da pomažu parovima razgovarati o njihovim teškoćama i željama, savjetovanja o različitim obiteljskim problemima (ovisnosti, nevjere i nasilje u obitelji), duhovne programe, radionice za roditelje s problematičnom djecom i obiteljske sastanke.«

U istom broju stoji izričito: »Župni ured trebao bi biti spreman srdačno očekivati i pokazati osjetljivost za obitelji u potrebama ili ih jednostavno upućivati na one koji im mogu pomoći $\ll^{82}$.

Nije međutim rijetkost, nastavlja Amoris laetitia, da mnogi kada sklope brak nestanu iz župne zajednice. Pastoralni radnici pozvani su koristiti se svim prilikama da ih

\footnotetext{
${ }^{79}$ Isto, br. 227.

${ }^{80}$ Isto, br. 228.

${ }^{81}$ Isto.

${ }^{82}$ Isto, br. 229.
} 
pozovu i vrate u crkveno zajedništvo. Mogu se za to koristiti drugim sakramentima, kao što su krštenje djece, prva pričest, potvrda djece, ili nekim drugim prilikama, sprovodom, vjenčanjem, blagoslovom obitelji (kuća), ili - navodi pobudnica - boravkom Gospine slike u blizini ${ }^{83}$. Sve treba činiti u skladu s ekleziologijom izlaženja, izgrađujući Crkvu koja ide ljudima: $\gg$ Danas obiteljski pastoral mora biti bitno misionarski, pastoral u kojem se izlazi van među ljude i izražava im se blizinu. Ne možemo više biti poput tvornice tečajeva, koji su u najvećem dijelu slabo posjećeni ${ }^{84}$.

Među Izazovima kriza unutar VI. poglavlja pobudnica govori kako bračni život i obitelj mogu napasti $\gg$ krize svih vrsta, ali one su sastavni dio njezine dramatične ljepote $\ll{ }^{85}$. Svladavanje kriza osnažuje odnose, bolje povezuje ljude, biva se sretan na nov način. Svaka kriza izazov je za dobro i bolje i ne bi se smjelo dogoditi donošenje brzopletih odluka. Pobudnica plastično opisuje kako ljudi redovito reagiraju u krizama braka. Najprije se pruža otpor, pokazuje obrambeni stav, jer nam kriza izmiče i njome ne možemo vladati. Stvara nam neugodu i mi uzmičemo da se $s$ krizom suočimo. Zatim se pribjegava nijekanju problema, skrivanju ili umanjivanju njihove važnosti, nadajući se da će s vremenom sve proći i da će se sve nekako razriješiti. A zapravo se pogoršava, rasipa se energija, odgađaju rješenja, veza slabi, a jača udaljavanje i izolacija, šteti se intimnosti i ugrožava komunikacija. Od osobe koja je nekada bila osoba koju volim polako postaje suputnik pa onda otac ili majka moje djece i na koncu nepodnošljivi stranac ${ }^{86}$.

S krizama se treba uhvatiti u koštac, ne povući se $\gg$ u kukavičku i prijetvornu šutnju «. Ništa u krizama nije tako neophodno kao komunikacija, razgovor, jasna je Amoris laetitia. Razgovarati valja učiti još u vremenu mira, sloge, kako bi nam razgovor pomogao u teškim trenutcima ${ }^{87}$. Osim raznih kriza koje prate obitelj (prihvaćanje razlika, odvajanje od roditelja i odnos s njima, rađanje i odgoj djece) postoje i one osobne, od financija, problema s poslom i na poslu, razdvojenosti zbog posla,

\footnotetext{
${ }^{83}$ Usp. isto, br. 230.

${ }^{84}$ Isto.

${ }^{85}$ Isto, br. 232. »Postoje krize koje se obično događaju u svakom braku, poput krize na početku braka, kad treba naučiti kako uskladiti međusobne razlike i odvojiti se od svojih roditelja; ili krize koja se javlja po rođenju djeteta, s novim emocionalnim izazovima; krize pri podizanju djece, koja zahtijeva promjenu načina života i navika roditeljâ; krize koja se javlja kad dijete uđe u adolescentsku dob, koja zahtijeva velika naprezanja, destabilizira roditelje i često stvara napetosti među njima; krize 'praznog gnijezda' koja prisiljava par da ponovno sagleda svoj odnos; krize izazvane starošću roditeljâ bračnih drugova, koji traže više njihove prisutnosti, pozornosti te donošenja teških odluka. To su zahtjevne situacije, koje izazivaju strah, osjećaj krivnje, očaj ili umor, koji mogu imati ozbiljne posljedice za brak « (Isto, br. 235).

${ }^{86}$ Usp. isto, br. 233.

${ }^{87}$ Usp. isto, br. 234.
} 
do raznih bolesti i emocionalnih poteškoća, pa može doći do uzajamnoga optuživanja. Uvijek je pritom važno znati i moći oprostiti ${ }^{88}$.

Neki od supružnika opet smatraju da ako im se nije ostvarilo ono što su očekivali imaju posve dovoljan razlog za raskid braka (dovoljno je ponekad nešto sasvim malo, malo razočaranje, neki osjećaj samoće, čak vremenski kratka odsutnost drugoga, povrijeđen ponos ili neodređeni strah), osjećaj nepoštovanja, nepodnošenja neke razlike ili afiniteta ${ }^{89}$. Dok se neki hrabro suočavaju $s$ tim krizama ${ }^{90}$, neki ne uspijevaju, nego upadaju u krize ili se rastavljaju, a neki nastavljaju živjeti nepomireni, njeguju stare rane i ostaju u emocionalnoj nezrelosti. Neki tek u četrdesetoj postižu ono što su trebali postići u adolescenciji, neki ostaju nezreli čitava života. Pobudnica detektira neka iskrivljenja u ljubavi i očekivanjima u braku:

$\gg$ Nekad se voli egocentričnom i hirovitom ljubavlju, svojstvenom djetetu, koja je zapela u fazi u kojoj se ima iskrivljen pogled na stvarnost i misli se da se sve mora vrtjeti oko vlastitoga 'ja'. To je nezasitna ljubav koja vrišti i plače kad ne uspije dobiti ono što želi. Katkad se voli ljubavlju koja je ostala u fazi adolescencije, označenoj buntovništvom, jetkom kritikom i navikom da se za sve okrivljuje druge, koja je obuzeta vlastitim emocijama i maštama, u kojoj drugi trebaju ispuniti naše praznine i udovoljiti našim hirovima $\ll{ }^{91}$.

Nijedan odnos u ljudskom životu ne prolazi bez tragova, pogotovo ljubavni, prijateljski i bračni odnosi. I ništa se tako ne odražava na zajednički život kao iskustvo voljenja ili nevoljenja u djetinjstvu. »Mnogi prožive čitavo djetinjstvo «, stoji u pobudnici, »a da nikada nisu oćutjeli bezuvjetnu ljubav. To utječe na njihovu sposobnost povjerenja u druge i darivanju samih sebe $\ll^{92}$. Neki nose traume iz djetinjstva, što se onda odražava na brak jer nisu osjetili da su ljubljeni ${ }^{93}$. Nije rijetkost susresti ljude koji kao da su nesposobni za ljubav ili neke koji kao da su rođeni uvrijeđeni i razmaženi, škrti u govoru, još više u djelima ljubavi, koji se ne koriste osnovnim

\footnotetext{
${ }^{88}$ Usp. isto, br. 236. »Nekim obiteljima prijeti rasulo kad supružnici upadnu u začarani krug uzajamnog optuživanja, no 'iskustvo pokazuje da se uz prikladnu pomoć i djelovanje milosti pomirenja veliki postotak bračnih kriza prevladava na zadovoljavajući način. Znati oprostiti i osjetiti da nam je oprošteno temeljno je iskustvo u obiteljskom životu'« (Isto.).

${ }^{89}$ Usp. isto, br. 237.

${ }^{90}$ Usp. isto, br. 238.

${ }^{91}$ Isto, br. 239.

${ }^{92}$ Isto, br. 240. »Loš odnos s roditeljima i braćom i sestrama, koji nije nikad popravljen, može se ponovno pojaviti i štetiti bračnom životu. Tada treba učiniti proces oslobođenja, s kojim se nije nikada suočilo « (Isto.).

${ }^{93}$ Usp. isto.
} 
riječima kao što su: smijem li, molim, hvala, oprosti ${ }^{94}$, koji i bližnje koji ih vole kažnjavaju okrivljivanjem, šutnjom ili drskošću zanovijetanja, koji traže posvemašnju slobodu ponašanja i istodobno da na njih svi misle i da se za njih svi brinu.

U problematičnim situacijama, u situacijama neslaganja i konflikta, pri pritisku da se mora donijeti sudbonosna odluka za oboje supružnika, svatko od supruga treba, nastavlja pobudnica, koliko može, suočiti se sa svojom traumatiziranom prošlošću i s mogućom nezrelošću: »Svatko mora biti iskren prema sebi kako bi spoznao da njegov način življenja ljubavi izražava nezrelost $\ll^{95}$. Čak ako je i krivnja na drugome, nitko ne smije čekati da krizu rješava samo onaj drugi niti da se problem razriješi sam od sebe, nego je nužno odmah djelovati, ne otezati razgovor i suočavanje $s$ problemom te u sigurnosti Božje pomoći opraštati i moliti za oproštenje. ${ }^{96}$ Pritom je važno ne upasti u rezignaciju, ne posustati u obavljanju svojih svakodnevnih dužnosti, supružničkih i roditeljskih, nego ih, naprotiv, obavljati s još većim marom i založnošću, i to ne zbog nekoga prkosnoga dokazivanja svoje ispravnosti, nego radi dobra supružnika i dobra vlastite obitelji.

\subsection{Pastoral u tragediji Rastave - Nitko izopĆEN}

U III. poglavlju (Pogled upravljen Isusu: Poziv obitelji) u kristocentričnom ključu pobudnica govori o naravnim svojstvima ženidbe i izvan kršćanstva (Sjeme riječi i nesavršene situacije). S posebnom suosjećajnošću i razlučivanjem treba gledati na brakove drugih religijskih tradicija. I njih rese svojstva kao što su jedinstvo, otvorenost životu, vjernost i nerazrješivost braka ${ }^{97}$. S obzirom na nerazrješivost, pobudnica traži da se ne shvaća kao nametnuti teret, nego kao Božji dar: »Nerazrješivost ženidbe ('Što... Bog združi, čovjek neka ne rastavlja', Mt 19,6) ne smije se shvaćati

\footnotetext{
${ }^{94} \gg \mathrm{U}$ obitelji treba koristiti tri riječi. Želim to ponoviti. Tri riječi: molim, hvala i oprosti. To su tri ključne riječi. Kada u obitelji nema previše nametljivosti i kada se nauči reći 'molim', kada u obitelji nema egoista i kada se u njoj nauči reći 'hvala', i kada u obitelji neki njezin član primijeti da je učinio nešto loše i zna reći 'oprosti', tada u toj obitelji vladaju mir i radost. Ne budimo škrti u korištenju tih riječi, budimo velikodušni u njihovu ponavljanju iz dana u dan, jer neke šutnje bole i tište, katkad i u obitelji, između muža i žene, između roditelja i djece, među braćom i sestrama. Naprotiv, prave riječi, izrečene u pravom trenutku, štite i hrane ljubav iz dana u dan « (Isto, br. 133). Usp. također: K. SCHLÖGEL-FLIERL, »Drei Worte: 'darf ich?', 'danke' und 'entschuldige' « (AL 133). Über das Gelingen des Familienlebens aus der Perspektive von 'Amoris laetitia', u: G. AUGUSTIN, I. PROFT (ur.), Zum Gelingen von Ehe und Familie, 222-233.

${ }^{95}$ AL, br. 240.

${ }^{96}$ Usp. G. M. HOFF, Die schöpferische Macht der Vergebung. Theologische Reflexion aus Anlass von Amoris laetitia, u: G. AUGUSTIN, I. PROFT (ur.), Zum Gelingen von Ehe und Familie, 329338.

${ }^{97}$ Usp. AL, br. 72.
} 
kao 'jaram' nametnut ljudima, nego kao 'dar' koji se daje osobama združenima u bračnu zajednicu $\ll^{98}$.

Zasebni odjeljak VI. poglavlja o pastoralu braka i obitelji naslovljen je Praćenje nakon prekida i rastave (AL, br. 241-246). Navodi se da su u slučajevima pretjeranih zahtjeva, velikih nepravdi, nasilja ili stalnih zlostavljanja supružnici pozvani da se odupru kako bi sačuvali svoje dostojanstvo ${ }^{99}$ ili dobro djece. U pojedinim slučajevima izvana nije moguće vidjeti teška stanja i nesnošljive torture koje netko podnosi u braku i obitelji do mjere da je rastava neizbježna i nužna: »Treba shvatiti 'da postoje slučajevi u kojima je rastava neizbježna. Katkad može postati čak i moralno nužna, kad je potrebno slabijega bračnog druga ili malu djecu sačuvati od težih rana, prouzročenih arogancijom i nasiljem, ponižavanjem i izrabljivanjem, zastranjivanjem i ravnodušnošću' « ${ }^{100}$. Pobudnica istodobno navodi Familiaris consortio (1981., br. 83) ${ }^{101}$ da, ipak, »rastavu možemo smatrati samo nekim krajnjim lijekom pošto se svaki drugi razumni pokušaj pokazao uzaludnim $\ll{ }^{102}$.

I ovdje se, u kontekstu rastave, koristi jednim od temeljnih termina za tu pobudnicu - razlučivanje. Razlikuju se razvedeni, rastavljeni i ostavljeni; traži se razlikovanje kriza, vrjednovanje patnji, prosudba nesretnih okolnosti za bračne odnose; traži se pomoć biskupijskih savjetovališta i prihvatilišta, poticanje na euharistiju gdje nema zapreke te prihvaćanje u crkvenu zajednicu i onih koji su rastavljeni i ponovno u braku. Pobudnica izričito kaže da se nitko ne smije osjetiti izopćenim iz Crkve. Dva su broja (AL, br. 242 i 243) u tom smislu iznimno važna, pa ih zbog delikatnosti njihova sadržaja i pastoralnih zahtjeva donosimo u cjelini:

$\gg$ Sinodski su oci primijetili: 'Posebno razlučivanje nužno je za pastoralno praćenje razvedenih, rastavljenih i ostavljenih. Treba prije svega vrednovati patnju onih koji su nepravedno pretrpjeli rastavu, razvod ili ih je bračni drug napustio, ili su zbog zlostavljanja kojima su bili izloženi

\footnotetext{
${ }^{98}$ Isto, br. 62.

${ }^{99}$ Usp. I. PROFT, Amoris laetitia - Über personale Würde und Gelingen der Freiheit, u: G. AUGUSTIN, ISTI (ur.), Zum Gelingen von Ehe und Familie, 244-259.

${ }^{100}$ AL, br. 241.

${ }^{101}$ Pobudnica Familiaris consortio u br. 84. poručuje pastirima da su zbog ljubavi prema istini obvezani dobro razlučivati situacije jer » postoji razlika između onih koji su se iskreno naprezali da spase prvi brak, a napušteni su posve nepravedno, i onih koji su svojom teškom krivnjom razorili kanonski valjan brak. Na koncu postoje i oni koji su stupili u novo zajedništvo radi odgoja djece i katkad su subjektivno svjesni u savjesti da prethodni brak, nepopravljivo razoren, nikada nije bio ni valjan.« O pobudnici FC i dokumentima učiteljstva koji su uslijedili poslije usp. M. OMETTO, Divorziati che vivono una nuova unione nella Chiesa cattolica, 69-83.
}

${ }^{102}$ AL, br. 241. 
od bračnog druga bili prisiljeni prekinuti zajednički život. Oprostiti pretrpljenu nepravdu nije lako, ali to je hod koji omogućuje milost. Otud nužnost pastorala pomirenja i posredovanja također s pomoću prihvatilišnih centara koje treba osnovati u biskupijama.' Istodobno, 'rastavljene osobe koje se nisu ponovno oženile, koje su često svjedoci bračne vjernosti, treba poticati da u euharistiji pronađu hranu koja će ih podupirati u njihovom životnom stanju. Lokalna zajednica i pastiri moraju pratiti te osobe s brižnošću, posebno ako su s njima djeca ili žive u teškom siromaštvu'. Bračni krah postaje još traumatičniji i bolniji kada su posrijedi siromašni, jer raspolažu s daleko manje sredstava za otpočinjanje novog života. Siromašna osoba, koja ostane bez sigurnoga obiteljskog okruženja, dvostruko je izloženija napuštanju i svakoj vrsti opasnosti po vlastiti integritet $\ll^{103}$.

$\gg$ Razvedenima koji su stupili u novu vezu ${ }^{104}$ važno je omogućiti da se osjećaju dijelom Crkve. 'Oni nisu izopćeni' i ne bi trebali biti tretirani kao takvi, jer ostaju dio crkvene zajednice. Te situacije zahtijevaju pomno razlučivanje i praćenje ispunjeno poštovanjem, izbjegavajući svaki govor i stajalište zbog kojih će se oni osjetiti izopćenima i promičući njihovo sudjelovanje u životu zajednice. Briga koja se posvećuje tim osobama ne slabi vjeru zajednice i njezino svjedočenje o nerazrješivosti ženidbe, nego, štoviše, ona upravo po toj brizi izražava svoju ljubav $\ll{ }^{105}$.

U nastavku, a što je među glavnim novostima pobudnice, traži se pojednostavljivanje i ubrzavanje ženidbenoga postupka u slučajevima kada postoje uvjeti da se brak proglasi ništavnim. ${ }^{106}$ I to je jedna od najkonkretnijih uputa pobudnice. Važno je da bračni parovi znaju da imaju na raspolaganju obavijesnu, savjetničku i posredničku

${ }^{103}$ Isto, br. 242.

${ }^{104} \mathrm{U}$ pobudnici se koristi izrazom »divorziati che vivono una nova unione «, nova veza (zajedništvo) koja može, a i ne mora biti civilno-pravno regulirana. Kod nas se različito, a negdje i netočno prevodi: $\gg$ razvedeni koji su stupili u novu vezu « (AL, br. 243), »rastavljeni koji su stupili u novu vezu « (AL, br. 246), »rastavljeni i ponovno vjenčani « (AL, br. 297), »rastavljene osobe koje su sklopile novi brak $\ll$ (AL, br. 298).

${ }^{105}$ Isto, br. 243.

${ }^{106}$ Motuproprijima iz 2015. godine Mitis iudex Dominus Iesus i Mitis et misericors Iesus (za istočne Crkve) papa Franjo poduzeo je temeljitu reformu pojednostavljivanja kanonskoga procesa poništenja braka: ukidanje dvostrukoga pravorijeka, kratkoća procesa, središnje značenje biskupa i veza s redovnim pastoralom (usp. M. OMETTO, Divorziati che vivono una nuova unione nella Chiesa cattolica, 128-131.). 
službu u biskupiji ${ }^{107}$, kao i da biskupi imaju prvu i glavnu odgovornost u prosudbi pojedinih slučajeva za ništavnost braka. ${ }^{108}$

Uz navedeno, papa Franjo, kao i na nekim drugim mjestima pobudnice, intervenira u ja formi kada zahtijeva da djeca ne smiju biti taoci roditelja, njihovih loših odnosa, rastava i razvoda. $\mathrm{Na}$ djecu se ne smije svaliti teret rastave niti se smije njima koristiti protiv drugoga bračnoga druga. ${ }^{109} \gg$ Neodgovorno je omalovažavati drugoga roditelja kako bi se zadobila djetetova ljubav, radi osvete ili da bi se opravdalo samoga sebe, jer će se time nanijeti šteta djetetovoj duši i nanijeti rane koje teško zacjeljuju $\ll^{110}$.

Pobudnica ničim ne opravdava razvod niti u upitnost dovodi nerazrješivost sakramenta ženidbe, nego jasno kaže: »Razvod je zlo i vrlo zabrinjava sve veći broj razvoda. Stoga je, nedvojbeno, naša najvažnija pastoralna zadaća, koja se odnosi na obitelji, ojačati ljubav i pomoći zacjeljivanju rana, te raditi na tome da se spriječi širenje te drame našega doba ${ }^{111}$.

Među složene okolnosti za pastoral braka i obitelji pobudnica ubraja mješovite ženidbe i ženidbe supružnika različitih vjera. Dokument skreće pozornost na unutarnju vrijednost mješovitih brakova, na mogućnost njihova doprinosa ekumenizmu $^{112}$, uz pridržavanje normi s obzirom na zajedničku euharistiju. Ženidbe supružnika različite vjere, koje su u svijetu sve brojnije, traže više pastoralne skrbi »prilagođene različitim društvenim i kulturnim okruženjima «. One mogu biti »povlašteno mjesto međureligijskog dijaloga « i dokaz »poštovanja vjerske slobode $\ll{ }^{113}$, iako ima zemalja gdje to uopće nije slučaj.

${ }^{107}$ Usp. AL, br. 244.

${ }^{108}$ Jednoznačno se naglašava u pobudnici da biskup $\gg$ u svojoj Crkvi, u kojoj je postavljen za pastira i poglavara, po svojoj je naravi sudac među vjernicima koji su mu povjereni«. Važna je »dužnost biskupskih ordinarijata, koji su pozvani sami prosuditi određene slučajeve i na svaki način vjernicima omogućiti lakši pristup pravdi. To, pak, traži pripravu dostatnog osoblja, koje čine svećenici i laici, kojima je bavljenje tom crkvenom službom prioritet (Isto, br. 244).

$109 \gg$ Rastavljenim roditeljima upućujem ovu zamolbu: 'Nikada, nikada, nikada ne uzimajte dijete za taoce! Rastali ste se jedno od drugoga zbog mnogih teškoća i razloga, život vam je dao tu kušnju, ali neka djeca ne budu ta na koju će se svaliti teret te rastave, neka ih se ne koristi kao taoce protiv drugog bračnog druga, neka rastu slušajući mamu kako dobro govori o tati, premda nisu zajedno, i da tata dobro govori o mami' $\ll$ (Isto, br. 245).

${ }^{110}$ Isto.

${ }^{111}$ Isto, br. 246.

${ }^{112}$ Usp. isto, br. 247. Usp. M. WITZENBACHER, Sakrament oder 'weltlich Ding'? Impulse für ein ökumenisches Eheverständnis aus 'Amoris laetitia', u: G. AUGUSTIN, I. PROFT (ur.), Zum Gelingen von Ehe und Familie, 154-186.

${ }^{113}$ AL, br. 248. 
Amoris laetitia stalno traži da se Crkva, a onda i pastoralni radnici, u svim, a posebice $\mathrm{u} \gg$ složenim ženidbenim okolnostima «, po bezgraničnoj ljubavi izjednačuju s Kristom. Dokument ponovno navodi Misericordiae vultus, br. 12 i kaže: »Crkva se mora ugledati na Gospodina Isusa koji u svojoj bezgraničnoj ljubavi ide ususret svakoj osobi, bez iznimke ${ }^{114}$. U nastavku stoji da su velika briga homoseksualni članovi u obitelji. Prema osobama različite seksualne orijentacije treba se odnositi bez diskriminacije, u poštovanju dostojanstva njihove osobe, a tim obiteljima $\gg$ zajamčiti obzirno pastoralno vodstvo ${ }^{115}$. Rezolutno se pak odbacuje svako izjednačavanje veze homoseksualnih osoba sa ženidbom i Božjim naumom braka i obitelji ${ }^{116}$. Ne propušta se međutim zahtijevati brižnu pozornost i konkretnu pomoć obiteljima samohranih roditelja ${ }^{117}$.

Posljednji dio VI. poglavlja posvećen je govoru o smrti voljene osobe. Nužno je, traži Amoris laetitia, da pastoralni radnici kao potporu obiteljima kojima je netko od članova umro ponude $\gg$ svjetlo vjere $\ll{ }^{118}$. Smrt izaziva razne krize, i krizu vjere, čak u teškom obliku i optuživanje Boga. Udovištvo može biti iznimno teško iskustvo $^{119}$. Tugovanje za umrlim supružnikom, ili članom uže obitelji, obično traje dugo. Vrijedi i potrebno je, nastavlja pobudnica, osobi koja tuguje kazati da

»još uvijek pred sobom ima misiju koju treba ispuniti, te da nije dobro produljivati patnju, kao da je riječ o svojevrsnom odavanju počasti. Umrla voljena osoba ne treba našu patnju, niti joj je lakše što uništavamo svoje živote. Najbolji izraz ljubavi također nije sjećati se i spominjati ju u svakom trenutku, jer to znači ostati privezan uz prošlost koje više nema, umjesto da se ljubi stvarnu osobu koja se sada nalazi na drugome svijetu $\ll{ }^{120}$.

$S$ vjerom i pouzdanjem treba pratiti osamljene, svjedočiti im da nisu sami, da ih prate i njihovi bližnji na nebu ${ }^{121}$.

Iskustvo zajedničkoga života pokazuje paradokse. Naime nemiri i praznine poslije smrti bližnjega ostaju bez obzira na sve utjehe i molitve. Kao i da sam Bog ne želi

\footnotetext{
${ }^{114}$ Isto, br. 250.

${ }^{115}$ Isto.

${ }^{116}$ Usp. isto, br. 251. »Glede planova da se zajednice homoseksualnih osoba izjednače sa ženidbom, 'nema nikakve osnove za prihvaćanje niti uspostavu sličnosti, pa ni daleke, između homoseksualnih zajednica i Božjega nauma o braku i obitelji’ (Isto.).

${ }^{117}$ Usp. isto, br. 252.

${ }^{118}$ Isto, br. 253.

${ }^{119}$ Usp. isto, br. 254.

${ }^{120}$ Isto, br. 255.

${ }^{121}$ Usp. isto, br. 257.
} 
popuniti prazninu koju osjećamo poslije odlaska voljene osobe i kao da nam želi kazati da trebamo osjeti koliko nam je ta osoba značila. No s druge strane također postoji paradoks. G. Cucci primjećuje da onaj »tko je proživio lijep i zadovoljavajući odnos manje pati zbog gubitka supružnika u odnosu na onoga koji je živio nesretnu i konfliktnu relaciju. U ovom potonjem slučaju čini se da zajedno s bolom gubitka na vidjelo izbija također i žal što su se prokockale važne mogućnosti vlastitoga života kad se moglo živjeti na drukčiji način. ${ }^{122}$

Pastoral praćenja bračnih i obiteljskih zajednica predstavlja kršćansku nesebičnu zauzetost i blizinu supružnicima, njihovoj djeci, pogotovo ranjenima, ostavljenima i rastavljenima, ožalošćenima smrću. Zanimanje za druge u složenim okolnostima nikada nije usmjereno na unošenje još većega razdora, na širenje laži, na difamaciju i lažno sablažnjavanje nad grijesima drugih, nego na pomoć, na ozdravljenje, na stvaranje obnovljenoga zajedništva u ljubavi. I kada svi odu ili ih napuste, supružnici, zajedno ili pojedinačno, trebaju osjetiti da ih prihvaćaju njihovi svećenici, pastoralni radnici, odnosno crkvena zajednica treba ostati mjesto njihova prihvata, Božji dom sigurnosti i utjehe. Kristov način djelovanja kao dobroga pastira, pastira ljubavi i milosrđa treba biti obvezujući uzor pastoralnim radnicima u razlučivanju okolnosti i osobne krivnje, odgovornosti i patnje, potpore i utjehe pojedinim supružnicima, djeci i unesrećenim obiteljima.

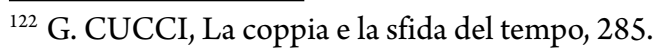




\title{
SOME GUIDELINES FOR THE PASTORAL CARE OF MARRIAGE AND FAMILY ACCORDING TO THE APOSTOLIC EXHORTATION AMORIS LAETITIA (I.)
}

\author{
Ivan ŠARČEVIĆ*
}

Summary: The first part of the article $\gg$ Some Guidelines for the Pastoral Care of Marriage and Family According to the Apostolic Exhortation Amoris Laetitia « wants to point out that the post-synodal exhortation on love in the family Amoris laetitia (2016) is marked by the pastoral theology of Pope Francis who builds upon his program exhortation Evangelii Gaudium (2013). The hallmarks of this theology are the biblical foundation and linguistic actualization, the Argentine theology of the people, the Jesuit spirituality with an emphasis on self-education through the formation of conscience and the discernment of spirits; the ecclesiology of the Second Vatican Council with an emphasis on the Church with open doors that goes forth to the peripheries. It is a pastorally oriented discourse on the God of gradual upbringing and unconditional mercy. It is about man, a beloved creature of God who is not perfect but is called to be brought up, to love and in this way to gradually, in small steps, in marriage and family, in the Christian community and the world, to be conformed to Jesus Christ. This part of the article discusses the special pastoral guidelines arising from the exhortation Amoris Laetitia, which relate to the preparation for marriage and the pastoral accompanying of spouses and families.

Keywords: family, love, God of mercy, Church that goes forth, conscience, pastoral care of accompanying and discernment.

* Prof. Ivan Šarčević, Ph. D., Franciscan Theology in Sarajevo, Aleja Bosne Srebrene 111, 71000 Sarajevo, Bosnia and Herzegovina, ivansarst@gmail.com 